\title{
TIETEELLINEN TAIDEKOKEMUS - CHECKPOINT LEONARDO: TAIDEMUSEO LUONNONTIETEEN OPPIMISYMPÄRISTÖNÄ AINEENOPETTAJ AKOULUTUKSESSA
}

\author{
Sari Harmoinen \\ Oulun yliopiston kasvatustieteiden tiedekunta, Opettajankoulutuksen yksikkö • \\ sari.harmoinen@oulu.fi
}

Tiivistelmä Oulun yliopiston matematiikan ja luonnontieteen aineenopettajaopiskelijat $(n=50)$ toteuttivat Oulun taidemuseolla pääasiassa kouluille tarjottuja tiedettä ja taidetta yhdistäviä oppimispajoja. Pajoihin osallistujia oli yhteensä noin 360, ala- ja yläkoulusta, lukiosta sekä maahanmuuttajien aikuisryhmästä. Opiskelijat saivat kokemusta pajojen suunnittelusta ja totutuksesta erilaisten ryhmien kanssa. Pajojen pitäminen antoi tilaisuuden harjoitella oppimisen ohjausta luokkahuoneen ulkopuolella, monialaisena ilmiöpohjaisena oppimiskokonaisuutena.

Avainsanat opettajankoulutus, oppimisympäristö, ilmiöpohjainen, tiede, taide

\section{Taustaa}

Aineenopettajaopiskelijoilla on vuosi aikaa kasvaa opettajaksi, substanssiosaajasta tiedon jakajaksi. Kasvuprosessi on monivaiheinen ja siinä ovat osallisina sekä opiskelija itse että yliopiston opettajankoulutusjärjestelmä. Oulun yliopiston kasvatustieteiden tiedekunta sai tähän yhteistyöhön mukaan keväällä 2015 myös Oulun taidemuseon. Museolla järjestettiin toiminnallinen taidenäyttely Checkpoint Leonardo. Yliopistolta näyttelyn toteuttamisessa oli mukana ryhmät taidepainotteisia luokanopettajaopiskelijoita ja matemaattisluonnontieteellisten aineiden aineenopettajaopiskelijoita. Tässä artikkelissa keskitytään jälkimmäisiin. Projekti oli mielenkiintoinen, koska opettajaopiskelija toimivat sekä oppijoina että opettajina. Projekti toteutettiin noin 2 kuukauden pedagogisten opintojen jälkeen ja ennen harjoittelukoululla tapahtuvaa opetusharjoittelua. Suurimmalla osalla opiskelijoista ei siis ollut aiempaa opettajakokemusta.

Perinteisesti matemaattisluonnontieteelliset oppiaineet tulkitaan yhdeksi tiedekokonaisuudeksi ja Oulun yliopistossakin ne muodostavat yhden oppiaineryhmän aineenopettajakoulutuksessa. Vuonna 2015 ryhmään kuului 50 opiskelijaa. Ainedidaktiikan opinnoissa he olivat yhdessä sekä luennoilla että sekaryhmäharjoituksissa. Ainedidaktisissa harjoitusryhmissä he olivat omien pää- ja sivuaineopintojen mukaisesti. Sekaryhmäharjoitusten tarkoituksena oli tukea opettajaksi kasvua monioppiaineiseen koulumaailmaan, jossa arvostetaan sekä omaa että toisen oppiainetta, unohtamatta oppiaineen ominaispiirteitäja tapaa hahmottaa ilmiöitä. 


\section{Museo oppimisympäristönä}

Tuleva perusopetuksen opetussuunnitelma (OPS 2014) tuo aiempaa korostetummin esille ilmiöpohjaisen oppimisen. Samalla korostetaan monialaisia oppimiskokonaisuuksien, joissa huomioidaan paikalliset mahdollisuudet. Opetussuunnitelman (OPS 2014) mukaan oppilaille tulee tarjota mahdollisuus oppimiseen koulun ulkopuolella, erilaisissa oppimisympäristöissä.

Koulun ulkopuolisena oppimisympäristönä voi toimia museo tai tiedekeskus. Usein niiden merkitys nähdään virikkeiden antajani ja ajattelun sekä oppimisprosessin stimuloijina. Museo voidaan pitää Eshachin (2007) mukaan nonformaalina oppimisympäristönä, jolloin motivaatio oppimiseen tulee usein oppijan ulkopuolelta. Oppimiskokemusten tarjoamista koulun ulkopuolella tuleekin suunnitella ja valmistella samalla tavoin kuin muutakin opetusta, jotta sitä voitaisiin hyödyntää oppimisen resurssina (Griffin \& Symington, 1997; Eshach, 2007). Tyypillinen museovierailu on strukturoitu, oppaan vetämä luentomainen kierros, jossa oppilaiden roolina on liikkua yhtenä ryhmänä oppaan perässäja täyttää kyselylomake (Griffin \&Symington, 1997).

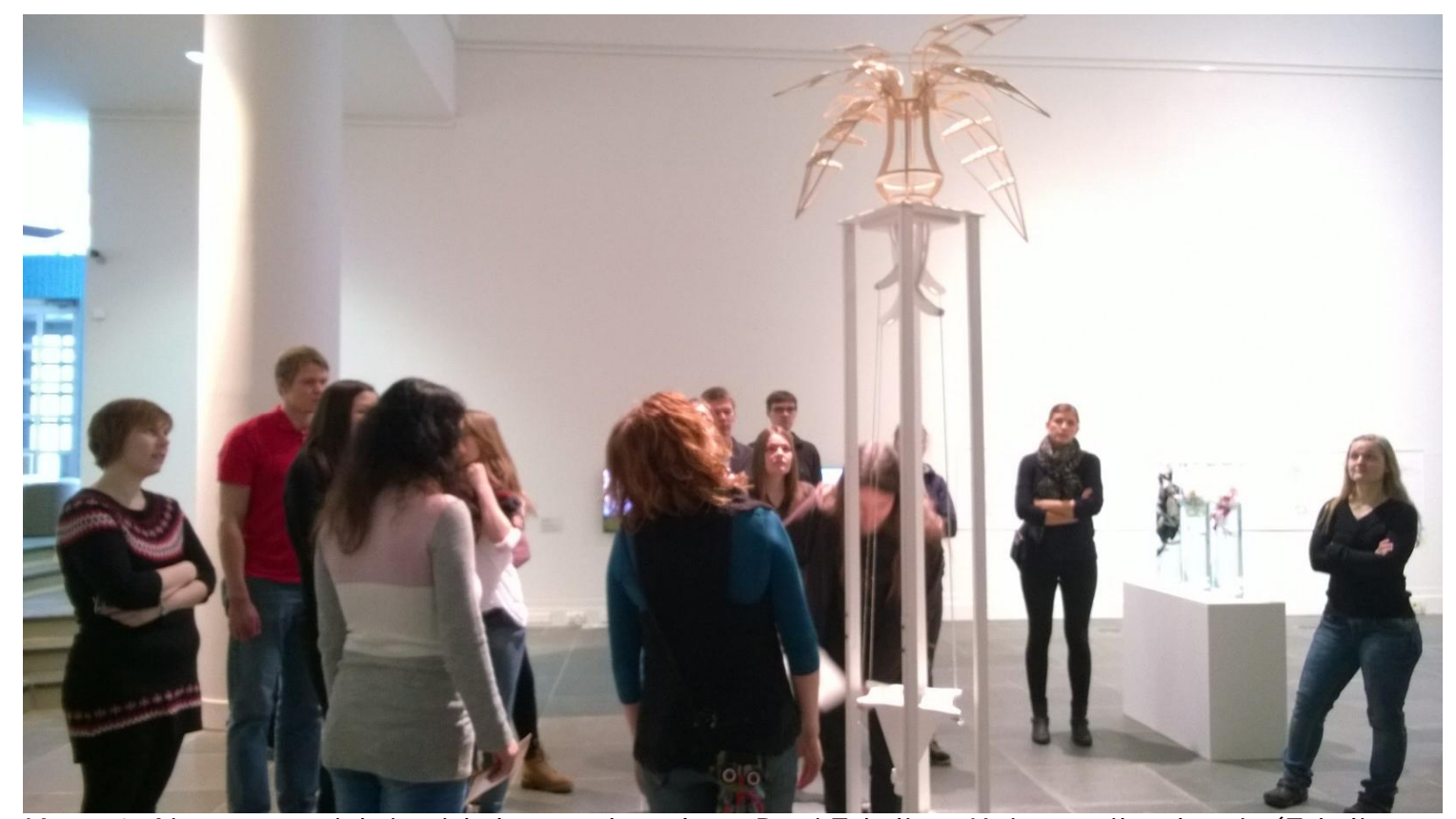

Kuva 1. Aineenopettajaksi opiskelevat tarkastelevat Petri Eskelisen Kuivan paikan kasvia (Eskelinen, 2015)

Tulevaisuuden taidoissa, usein puhutaan 21. vuosisadan taidoista, korostetaan muun muassa ajattelu- ja työskentelytapojen harjoittelua (Fullan \& Lanworthy, 2013). Näiden taitojen harjaannuttamisella tavoitellaan luovuuden, kriittisen ajattelun, oppimisen, kommunikoinnin ja informaation lukutaitoa. Näitä taitoja opettajien tulisi tulevaisuudessa opettaa myös oppilaille.

Oppimista ja opetusta tulisikin tapahtua kaikkialla ja kaiken aikaa. Erilaisten oppimisympäristöjen hyödyntäminen vastaa myös näihin haasteisiin. Luonnontieteiden oppimisessa korostetaan sosiaalista vuorovaikutusta ja puhetta, joka sidotaan ympäröivään 
maailmaan. J os esimerkiksi veden merkitystä lähdetään tarkastelemaan kuvassa 1 olevan Petri Eskelisen 'Kuivan paikan kasvin'-teoksen kautta, voidaan oppilaiden kanssa miettiä miten kasvissa saadaan vesi ylimpiin terälehtiin ja minne vesi menee sieltä, jne. Taideteos voi toimia keskustelun virittäjänä ja kokemusmaailmaan sitojana. Samalla luonnontieteellisestä tiedosta voi tulla osa yksilön tietoa, joka kehittää esimerkiksi hänen kriittisen ajattelun taitojaan (Osborne, 2007). Oppilaan kokemus synnyttää oppimista sekä uudistaa hänen ajattelua (Koivisto, Kukkola, Latomaa \& Sandelin, 2014). Siksi olisikin erittäin tärkeää, että oppilaiden arkikokemusten jakaminen olisi osa sosiaalisista vuorovaikutusta, oppimista ja omaa toimintaa, koska ne luovat erilaisia ja arvokkaita näkemyksiä tarkasteltavaan asiaan.

Koulun ulkopuolisella oppimisella tulee olla myös tavoitteet. Tavoitteet eivät välttämättä ole samat kuin perinteisessä luokkahuoneopetuksessa, vaan oppimista tulee ajatella uudella tavalla. Oppiminen on yhteisöllistä tiedon jakamista, huomioiden luovasti oppimisympäristö ja sen mahdollisuudet. Tässä esitellyn toiminnan tavoitteena oli tuottaa oppilaille kokemuksia, joissa pohjana olivat museossa esillä olleet taideteokset ja niiden pohjalta suunniteltu kokeellinen työpaja. Samalla opiskelijoita ohjattiin näkemään koulun ulkopuolisen oppimisympäristön mahdollisuuksia.

Tässä kirjoituksessa kerrotaan opettajaopiskelijoiden kokemuksista tarkastella taideteoksia yhtenä luonnontieteellisen kokeen havainnointimuotona sekä taiteen ja tiedon yhdistämisestä toisiinsa. Koska ilmiöt ja kokeelliset työt vaihtelivat eri pajoissa, tässä ei esitelläyksittäisiä töitä, vaan keskitytään opiskelijoiden kokemuksiin suunnitella ja toteuttaa koulun ulkopuolella tapahtuva oppimiskokonaisuus.

\section{Monialainen oppimiskokonaisuus}

Projektin tavoitteen oli järjestää ennalta sovitun aikataulun mukaisesti kahdelle koululaisryhmälle 90 min mittainen, museo oppimisympäristönä- vierailu. Käyntiin tuli liittää 2 - 3 näyttelyesineen esittely ja niihin pohjautuva kokeellinen työpaja biologian, fysiikan, kemian ja maantiedon asiasisältöihin liittyen. Opiskelijat asettivat ryhmänä itsenäisesti pajan tavoitteet sekä he vastasivat myös pajan sisällöstä. Opiskelijoiden rooli oli toimia ohjaajina ja opettajina museon näyttelyn ja niihin sidottujen työpajojen yhteydessä. Oppilaiden mukana ollut opettaja toimi yhtenä aikuisena, jolla ei ollut vetovastuuta.

Yliopistolla oli opiskelijoille ainedidaktiikan opinnoissa keväällä ennen museolla toteutettavaa toimintaa sekaryhmäharjoituksia yhteensä 8 tuntia. Tavoitteena oli harjoitella moniaineista työskentelyä, kasvattaa yhteistyötaitoja sekä uusien ideoiden luomista projektiluontoisesti yhteiseen ilmiöön pohjautuen. Ryhmät olivat 5 hengen moniaineisia sekaryhmiä ja ne olivat kaikissa harjoituksissa samat. Harjoituksista käytettiin kuusi tuntia työskentelyn harjoittelemiseen yhteisen ilmiön pohjalta. Kaksi tuntia käytettiin opiskelijoiden vierailuun Oulun taidemuseolla, jossajärjestettiin opastus näyttelyyn ja siellä oleviin esineisiin. Samalla heille esiteltiin museolla käytettävissä olevat tilat. Tämän jälkeen heillä oli mahdollisuus vierailla näyttelyssä omatoimisesti. Toteutusten jälkeen pidettiin 
lopputapaaminen, jossa jokainen ryhmä sai kertoa omista kokemuksistaan muille ryhmille. Lopuksi opiskelijoille tehtiin kysely google formsin kautta, johon vastasi 47 opiskelijaa. Heistä miehiä oli 17ja naisia 30.

Opiskelijoiden pajojen varaukset tehtiin keskitetysti Oulun taidemuseon kautta. Aineenopettajaksi opiskelevien työpajoja tarjottiin 18 kertaa Oulun kaupungin kouluille valittavaksi perusasteella ja lukiossa sekä maahanmuuttajaopetukseen kaikilla kouluasteilla. Yhdellä opiskelijaryhmällä oli kaksi pajaa perhepäivänä, joka oli avajaisten jälkeisenä lauantaina. Varausjärjestelmän kautta opettajaopiskelijoilla oli mahdollisuus nähdä pajaan osallistuvan ryhmän suuruus ja vuosiluokka. Tämä auttoi opiskelijoita suunnittelemaan pajan sisällön ikäkauteen sopivaksi.

\section{Opiskelijoiden kokemuksia museotyöskentelystä}

Aineenopettajaksi opiskelevat asettamat tavoitteet työpajalleen voidaan jakaa kolmeen luokkaan. Tavoitteet oli asetettu omalle työskentelylle, esimerkiksi "esitellä oppilaille veden ominaisuuksia kokeiden avulla", "pohtia yhdessä oppilaiden kanssa" tai "opettaa pajalaisia kierrättämään". Tavoitteina oli myös aktivoida oppilaat "oppimaan, ajattelemaan, herättää oppilaiden kiinnostusta ja ajatuksia". Lisäksi tavoitteena oli joillakin ryhmillä "osoittaa museon tarjoamassa oppimisympäristössä ryhmätyön ja kokeellisuuden..liittymäkohtia ympäristöön ja taiteeseen", "asennekasvatus" ja "tarjota mielenkiintoinen kokemus".

Työpajojen toteuttamisen parasta antia olivat seuraavat asiat: kokemuksen saaminen erilaisten ryhmien vetämisestä 55 \% (26 opiskelijaa) ja erilaisessa oppimisympäristössä työskentelystä $26 \%$ (12). Seitsemän opiskelijan (15\%) mielestä parasta oli kokemuksen saaminen ilmiöpohjaisen oppimisen toteuttamisessa. Kahden opiskelijan (4 \%) mielestä parasta oli itsensä haastaminen. Suurin osa opiskelijoista koki merkittävimmäksi erilaisten ryhmien ja erilaisessa oppimisympäristössä työskentelyn, joka oli ollut yksi pajatyöskentelyn tavoitteistakin.

Opiskelijoiden kokemuksen mukaan asiat, joihin he eivät olleet osanneet etukäteen varautua, liittyivät pääasiassa käytännön järjestelyihin, esimerkiksi taukojen puute, sama tila oli kahdelle eri ryhmälle varattu samaan aikaan ja olivat itse unohtaneet ottaajonkin pajassa tarvittavan välineen (esimerkiksi lapion) mukaan. Ryhmän kanssa toiminnassa opiskelijat eivät olleet osanneet varautua ryhmien erilaisuuteen, oman äänen riittävyyteen äänekkään ryhmän kanssa ja maahanmuuttajaryhmissä kielitaidon puute. Haasteellisena koettiin myös se, jos ryhmä ei ollutkaan sama ja saman ikäisistä oppilaista koostuva kuin mikä oli ilmoittautunut.

Lopuksi kysyttiin mitä sellaista museotyöskentelyssä oppi, johon vielä ei ollut saanut oppia ja opetusta. Esille nousi kaaoksen hallinta, nopeaa soputumista muutoksiin ja inspirointia. Ryhmän kanssa toimimisessa nousi esille oppi miten oppilasryhmän kanssa liikutaan ja siirrytään paikasta toiseen sekä kuinka ryhmää hallitaan ja ohjataan.

Kaiken kaikkiaan kokemus oli opiskelijoille hyvin antoisa. Opiskelijat kokivat mielekkäänä eri pääaineopiskelijoiden välisen yhteistyön, koska "projekti opetti luottamaan 
ryhmässä olevaan potentiaaliin sekä suunnittelussa että toteutuksessa”. Myös tieteen ja taiteen yhdistämisestä jäi "hyvä fiilis" ja "tämän tyyppisestä toiminnasta sai hyvin paljon irti". "Hieno kokemus, jollaista ei voisi monestakaan paikasta saada". Toivottavasti kokemus rohkaisee opettajaksi opiskelevia jakamaan kokemuksia sekä ymmärtämään erilaisten oppimisympäristöjen annin omassa tulevassa työssään. Illiciä (1970) lainaten: "Luokkahuoneopetus siirtää oppilaan kulttuurimme ulkopuolelle ja tunkee heidät ympäristöön, joka on monin verroin ulkopuolista ympäristöä alkeellisempi, luonnottomampi ja lisäksi kuolettavan vakava". Edellä esitetyt kokemukset opetuksen siirtämisen luokkahuoneen ulkopuolelle luovat kuvaa oppimisen onnistuneesta toteutuksesta, jossa yhdistyvät sekä tulevan opetussuunnitelman (OPS 2014) että tulevaisuuden oppimisen kehittämisen tavoitteet.

Kokonaisuutenaan kokeilu oli aikataulullisesti hyvin haastava, mutta erittäin onnistunut kokonaisuus. Tämän kaltainen toiminta tulisi sisällyttää jatkossakin opintoihin, koska opiskelijoiden onnistumisen ilo ja toisten oppiaineiden arvostuksen lisääntyminen oli selvästi havaittavissa. Yhteistyötaidot ja kriittinen ajattelu sekä tavoitteiden asettaminen, sekä itselle että oppilaille, saivat aivan uuden merkityksen, kun oppiminen siirrettiin luokkahuoneen ulkopuolelle. Oppiminen on muutakin kuin tiedon jakamista. Se on yhdessä kokemista, oppimisen iloa!

\section{Lähteet}

Cox-Peterson, A., Marsh, D., Kisiel, J . \& Melber, L. (2003). Investigation of guided school tours, student learning, and science reform recommendations at a Museum of Natural History. J ournal of Research in Science Teaching, 40 (2), 200 - 218.

Eshach, H. (2007). Bridging In-school and Out-of-school Learning: Formal, Non-Formal, and Informal Education. J ournal of Science Education and Technology, 16 (2), 171- 190.

Eskelinen, P. (2015) kuva heattu sivuilta: http:// www.petrieskelinen.net/

Fullan, M. \&Lanworthy, M. (2013) Toward a New End New Pedagogies for Deep Learning. Saatavilla http:// www.newpedagogies.info.

Griffin, J . \& Symington, D. (1997). Moving from task-oriented strategies on school excursions to museums. Science Education, 81(6), 763 - 779.

Illich, L. (1972). Kouluttomaan yhteiskuntaan (suomentanut Valpola, A.). Delfiinikirjat, Helsinki: Otava.

Koivisto, K., Kukkola, J., Latomaa, T. \& Sandelin, P. 2014. (toim.) Kokemuksen tutkimus IV. Annan kokemukselle mahdollisuuden. LUP Lapin Yliopistokustannus.

Opetushallitus (2014). Perusopetuksen opetussuunnitelman perusteet 2014.

Osborne, J . (2007). Science Education for the Twenty First Century. Eurasian J ournal of Mathematics, Science \&Technology Education, 3 (3), 173 - 184. 